\title{
BEYOND BIPOLAR: A THREE-DIMENSIONAL ASSESSMENT OF MONETARY FRAMEWORKS
}

\author{
Kenneth N. Kuttner \\ Assistant Vice President, Federal Reserve Bank of New York
}

Adam S. Posen

Senior Fellow, Institute for International Economics

\begin{abstract}
A great deal of attention has been focused recently on the impact of exchange rate regimes, just as previous empirical research examined central bank autonomy and announced targets for domestic monetary policy. To date, however, these three elements of monetary frameworks have been assessed in isolation from one another, and all have been viewed in terms of a unidimensional spectrum of fixity versus flexibility. Using a newly-constructed dataset, this paper jointly analyzes and compares all three elements' effects on inflation and exchange rate behavior. The results show that each of the three elements has independent and distinct effects on nominal outcomes. Key findings include: (1) although hard pegs do tend to reduce inflation and attenuate exchange rate fluctuations within some range, they are clearly characterized by large devaluations; (2) central bank autonomy is associated with a more stable exchange rate and lower inflation; and (3) explicit inflation targeting reduces both inflation and its persistence, consistent with the view that inflation targeting increases flexibility through transparency. These results raise the possibility that a combination of central bank autonomy, inflation targeting, and a free float might offer the same benefits as any intermediate exchange rate regime on its own, without the proclivity to occasional large depreciations.
\end{abstract}

$$
\text { JEL classifications: E52, E61, F33. }
$$

We are grateful to Morris Goldstein, Dale Henderson, Eduard Hochreiter, and participants in the Institute for Advanced Studies/Austrian National Bank Workshop on "Exchange Rate and Monetary Policy Issues" for comments, and to Christian Just for research assistance. Posen's work on this paper is part of the IIE's project on "Dollarization, Currency Blocs, and U.S. Foreign Policy." The views expressed here and any remaining errors are solely those of the authors, and not necessarily those of the Federal Reserve Bank of New York, the Federal Reserve System, or the Institute for International Economics.

"Copyright 2001 by the Institute for International Economics and the Federal Reserve Bank of New York. All rights reserved."

Kenneth N. Kuttner

Research Department

Federal Reserve Bank of New York

33 Liberty Street

New York, NY 10045
Adam S. Posen

Institute for International Economics

11 Dupont Circle NW

Washington, DC 20036 
In the aftermath of the financial crises of the 1990s, discussion of the appropriate exchange rate regime has mushroomed. There has been growing support for the idea that "corner solutions" — free float and currency union/dollarization — are the only long-run sustainable options for emerging markets, if not for all economies (Eichengreen and Hausmann 1999; Summers 2000). Still, "intermediate regimes" like currency baskets and bands also retain their advocates (notably Williamson 2000). Ironically, this movement to the ends of the fixity spectrum comes at the same time when there has been a yet stronger convergence of the intermediate monetary regimes (primarily inflation targeting) on the analogous domestic rules versus discretion spectrum (Bernanke, et al. 1999). Meanwhile, central bank independence has become the norm worldwide. Though the choice of domestic monetary and exchange rate regimes are obviously linked, and in some instances even jointly determined (as in a currency board arrangement), their effects controlling for the existence of the other has not been studied empirically.

All of these monetary measures - exchange rate arrangements, announced domestic targets, and increasing central bank autonomy — are commonly thought to provide a commitment mechanism: a credible basis for stable private-sector inflation expectations, albeit at the cost of some flexibility in response to macroeconomic shocks. ${ }^{1}$ Without such a commitment mechanism, the inflation bias of monetary policy is likely to rise, as is the proclivity for inflation shocks to persist. ${ }^{2}$ As argued in Kuttner and Posen $(1999 ; 2000)$, measures of the persistence of inflation and of exchange rate volatility are the macroeconomic variables which the choice of monetary framework could be expected to most consistently and directly affect. Assessments of the effect of exchange rate or domestic monetary regimes, which focus solely on macroeconomic outcomes, like average inflation levels or growth rates, are usually not robust to the inclusion of other explanatory factors like cyclical effects or structural changes. ${ }^{3}$ As explained in section two below, we believe that studies that classify exchange rate regimes by ex post behavior, e.g., that economies with large foreign exchange reserves and a habit of exchange rate intervention are by

\footnotetext{
${ }^{1}$ Rogoff (1985) first set out this tradeoff in the context of central bank independence, and others have made similar arguments with respect to exchange rate and domestic monetary commitments. This leaves aside the question as to whether that trend inflation rate should be positive, and if so how positive (as discussed in Akerlof, Dickens and Perry 2000), or whether price-level targeting should be pursued instead (as advocated in Svensson 1999). Whatever the numerical value of the optimal goal for monetary policy, the task of that policy is to bring and keep expectations in line with that goal with minimum real output cost and volatility.

${ }^{2}$ Walsh (1998), chapter 8 , gives a summary of these results from the theoretical literature.

${ }^{3}$ Ghosh, et al. (1997) and Levy-Yeyati and Sturzenegger (2001a,b) are recent studies which directly link exchange rate regimes with economic performance. Campillo and Miron (1997) gives a prime example of how many factors thought to affect inflation are insignificant when business cycle factors are included.
} 
definition not floaters (whether a peg is announced or not), tend to overlook this fact. More important, such efforts assume a negative answer to the analytically prior question: does the declared exchange rate regime (or announced domestic target) matter as a constraint on behavior?

In this paper, we take this question on as a matter for empirical investigation. To that end, we create a broad dataset of 191 monetary frameworks from 41 countries, using the term monetary framework to refer collectively to a combination of an economy's exchange rate regime, announced domestic targets on the conduct of monetary policy, and central bank autonomy. We then use that dataset to assess the effects of differing monetary frameworks on the behavior of exchange rates and inflation.

While Frankel (1999) and Fischer (2001) have set out many of the conceptual issues in the debate over exchange rate regimes, and some comparative case studies have been completed (Eichengreen, et al. 1998; Mussa, et al. 2000), to our knowledge this type of empirical exercise giving quantitative measures by declared regime type has not yet been undertaken. This paper makes two additional contributions to the current literature: first, we bring together measures of exchange rate regimes, announced domestic targets, and of central bank autonomy into one dataset, allowing us to assess their relative contributions; second, we employ econometric techniques, newly applied to this literature, appropriate for assessing the short-run flexibility/long-run stability tradeoff.

Our conclusions are in part supportive but largely opposed to the emerging consensus on polar approaches to exchange rates. Taking exchange rate regimes in isolation, our results confirm that hard pegs and currency boards do significantly diminish both exchange rate volatility and the level of inflation versus looser commitments or a free float. We also provide new evidence that hard pegs short of a currency union (or outright dollarization) have a clear tendency toward large occasional devaluations. Yet, this partial view taking exchange rates alone is misleading. In our results, when an economy's entire monetary framework is taken into account, the adoption of domestically based monetary constraints like inflation targeting or central bank independence - controlling for any exchange rate commitments - confer nearly the same benefits on the relevant measures versus a free float as do intermediate exchange rate regimes. Yet, these domestic measures come without the large abrupt depreciations in exchange rates associated with the harder exchange commitments evident in our data.

Moreover, the inflation targeting regime has the additional effect of significantly diminishing the persistence of inflation in the countries where it is adopted, consistent with a view that such a transparent 
framework allows the central bank to approach the flexible optimal state-contingent rule (King 1997). ${ }^{4}$ The experience of inflation targeters who tried to follow a relatively hard monetary conditions index seems to have demonstrated that there is some conflict between inflation targeting and a tight exchange rate commitment (as argued theoretically in Ball 1999 and empirically in Siklos 2000). Our results suggest the combination of inflation targeting plus exchange rate float (and central bank autonomy) would appear to be a full substitute for a hard exchange rate commitment in terms of inflation level/exchange rate depreciation, with an improvement in both exchange rate volatility and in inflation persistence.

Our paper is organized in four sections. Section one discusses further the nature of monetary frameworks, and why the three elements we consider plausibly affect the economy through separate channels of pre-commitment, transparency, and conservatism. Section two describes the construction of data on monetary frameworks for this paper's investigations. ${ }^{5}$ Section three sets out the econometric approach used in our empirical analyses and presents the results of those analyses. Section four offers our conclusions, and acknowledges a number of limitations of this study as a prompt to future research.

\section{HOW SHOULD MONETARY REGIMES MATTER?}

In the economics literature, different types of monetary regimes are usually lumped together as various means to make similar kinds of commitments to price stability. Such commitments by the issuer of fiat money, if believed by the public and the markets, act as a drag if not a limit on inflationary tendencies and/or depreciating the currency's value. Normally, economists concerned with the provision of a monetary commitment are thought to come from the rules (fixity) end of the rules-versus-discretion (fixityversus-float) debate. So, for example, Frankel (1999) writes:

Of the advantages of fixed exchange rates, academic economists tend to focus most on the nominal anchor for monetary policy. The argument is that there can be an inflationary bias when monetary policy is set with full discretion. A central bank that wants to fight inflation can commit more credibly by fixing the exchange rate, or even by giving up its currency altogether... When workers and firm managers have low expectations of inflation, they set their wages and prices accordingly. The result is that the country is able to attain a lower level of inflation for any given level of output...The strength of the argument for basing monetary policy

on an exchange-rate target will also depend on the availability of alternative nominal anchors such as money supply, nominal income, and price level. (9-10)

\footnotetext{
${ }^{4}$ To our knowledge, this paper is the first to document such an effect of inflation targeting for a large sample. Kuttner and Posen (1999) showed a significant decline in inflation persistence in Canada, New Zealand, and the United Kingdom, after adoption of inflation targeting, consistent with the optimal state-contingent rule.

${ }^{5}$ The appendix lists the various regime classifications by country and date in our sample.
} 
This last point, the potential availability and interaction of alternative means of commitment, is the empirical focus of our paper. In particular, we are interested in whether the various forms of exchange rate fixes, of announced domestic targets, and of central bank autonomy work in generally the same manner (making duplication of commitment mechanisms redundant), or whether they have differing effects in both degree and nature on monetary outcomes (making combinations of them distinct).

Consider the now standard expression that central bank independence or exchange rate targets "bind the hands" of monetary policymakers. This assumes that the only purpose of monetary regimes is to increase the credibility of commitments that central banks will not create surprise inflation. If the policymaker's wrists were already bound by exchange target duct tape, what would be the effects of an additional pair of handcuffs from inflation targets and yet another loop of rope in the form of central bank independence? One could argue that the effect would be nil, because the exchange rate commitment already credibly limited the central banker's discretion. One could instead argue the effect would be still greater credibility, albeit perhaps with diminishing returns, because inflationary government officials are escape artists, and the more restraints the better. Or one could argue that the additional restraints are counterproductive, because just handcuffs in the form of inflation targeting leave a necessary limited amount of discretion as well as a clear release method, while the excessively tight duct tape of exchange rate targets, let alone multiple constraints, interferes. Theory gives no single answer to this empirical question. ${ }^{6}$

In practice, all monetary frameworks are a matter of balancing commitment with flexibility. Thus, establishing empirically the differing ability of various monetary frameworks to meet this balance is of concern to monetary economists all along the rules-versus-discretion spectrum, rather than simply a matter of maximizing commitment through rules. As argued in Kuttner and Posen (1999), for purposes of empirical research, changing monetary regimes may be thought of as shifts between discretion, conservatism, or transparency by central banks, with clear implications in a standard time-inconsistency model of monetary policy for the volatility of output/exchange rates and for inflation persistence. Regimes that emphasize conservatism or rules to establish their counter-inflationary bona fides, usually entail a cost

\footnotetext{
${ }^{6}$ Most belief in the power of dollarization or currency unions takes the first view listed here, that the exchange rate commitment is all that counts. The designers of the euro-zone, perhaps reflecting the second view, clearly believed that central bank independence and inflation targets were useful adjuncts to the ERM commitments. We are sympathetic to the third hypothesis that too tight a rule-based commitment will increase the odds of the regime breaking down under stress. Drazen and Masson (1990) make this case in theoretical terms, and Eichengreen, et al. (1998) analyze the difficulties that emerge when overly tight commitments outlast their initial usefulness.
} 
in terms of lost flexibility in responding to real shocks in line with the tradeoff in Rogoff (1985) - shortrun volatility (of exchange rates and/or output) increases even as the commitment increases mean reversion in long-run inflation expectations. Regimes that somehow manage to successfully anchor long-run inflation expectations through transparency and communication, however, approaching King's (1997) optimal state contingent rule, are able to exert short-run flexibility in response to real shocks while also reducing inflation persistence.

The question at hand is therefore what the record shows about the different means used by monetary policymakers to anchor inflation expectations. So far, the literature and historical experience have offered three broad categories of candidates, but have tended to analyze their effects in isolation from each other:

P Exchange rate constraints - Visible public commitments by the central bank to uphold the value of the domestic currency against a particular currency or currencies. These vary from loose constraints of wide target zones to the extreme of dollarization or currency union where the domestic currency is replaced by the foreign 'anchor' currency. The more firm versions of exchange rate arrangements are the most literal forms of monetary rules we have in practice today, "tying the hands" of policymakers on a day-to-day basis. It is fair to think of these as simply ranging from least (float) to most (currency union) binding.

P Announced domestic targets - Publicly announced targets by the central bank for domestically set measures of monetary aggregates. These vary from short-term targets for narrow monetary aggregates under the central bank's control, like high-powered money, to multi-year targets for broader goals, like inflation targets. In practice, unless taken to the extreme of the currency board or union (in which case the exchange regime completely constrains monetary policy), these domestic arrangements rely on transparency to anchor inflation expectations by conveying policy and keeping it accountable for deviations.

P Central bank autonomy ${ }^{7}$ — Legal structures to insulate monetary policy from political pressures for monetary expansion. The practically relevant aspects of these laws have been shown to consist

\footnotetext{
${ }^{7}$ We refer to central bank 'autonomy' rather than the more commonly used 'independence' not due to any conceptual distinction, but in order to avoid confusion between the extant measures of CBI and those used in this paper. See the discussion in section two.
} 
of barriers to the firing of central bank governors and to the direct purchases of government debt from the fiscal authority by the central bank. ${ }^{8}$ These laws are meant to enhance the ability of central banks to pursue a course of relative conservatism in monetary policy, meaning a higher relative weight on inflation than output goals than held by the economy's median voter. This usually is thought to build the central bank's reputation, but also can mean greater instrument discretion for the central bank to pursue its goals.

Except in the case of currency union/dollarization, where the three regimes collapse into one alldetermining framework, the relationship between these three paths to a nominal anchor is unclear. The harder the exchange rate constraint, it might be presumed, the less important central bank autonomy or announced domestic targets - yet, arguably, the existence of central bank autonomy might make longer term commitments to exchange rate pegs more credible (diminishing perceptions that a devaluation might occur). Meanwhile, if reporting of monetary, credit, or inflation targets primarily serves a communicative rather than a binding function (as in Laubach and Posen 1998), it could supplement rather than cut against the exchange rate constraint. These relationships remain to be empirically established. Whether the achievement of the optimal state contingent rule, meaning a combination of increasing short-run flexibility and long-run counter-inflationary credibility, is in fact attainable, and how much the increasing precommitment of harder exchange rate arrangements gains over float, are also open questions for the data to address. That is the purpose of the rest of this paper.

\section{CONSTRUCTION AND CLASSIFICATION OF MONETARY FRAMEWORKS DATA}

Assessing the effects and effectiveness of monetary frameworks - and by extension, the roles of rules, transparency, and conservatism - naturally requires the measurement and classification of those frameworks. The first task, therefore, is to assemble a dataset containing information on the exchange rate regime, announced domestic target, and degree of central bank autonomy in effect at each point in time for a range of economies. Our starting point for exchange rate regimes and announced domestic targets is the annual IMF classifications of exchange rate arrangements. These classifications, however, are only given on an annual basis and at times seem to be at odds with central banks' self-descriptions, particularly in shorter-lived regimes. We therefore supplemented the information from this source with the addition of specific start and end months for each element of the framework, working from central bank data and a

\footnotetext{
${ }^{8}$ See Cukierman (1992), Eijffinger and deHaan (1996), and Posen (1999).
} 
variety of published sources by country. Available published measures of central bank independence are all given as multi-year averages, so from the start we had to compile and classify from primary sources. (A detailed list of these resulting cases is given in an appendix to this paper.) Monetary frameworks are coded as particular combinations of these three elements. A change in any one of these three elements is treated as a distinct monetary framework, and a new case is identified from the date of that change. An observation on one of the elements alone is referred to as a regime.

Rather than use IMF's fine-grained distinctions, we classify exchange rate regimes into four categories intended to capture the degree to which the regime imposes a rule on policy: "currency boards", which include official dollarization and currency unions as well; "hard pegs", which include all bilateral or firmly fixed ratio basket pegs; "target zones", which includes crawling pegs, frequently shifting baskets, as well as wide-band arrangements (like the ERM); and "free float." We do not distinguish between managed and "pure" free floating, as our decision to classify an economy as a floater depends solely upon the absence of any publicly declared exchange rate commitment (or upon a public commitment to float).

Our emphasis on declared regimes rather than on "revealed behavior" raises an important issue. Others studying exchange rates, for example, have chosen to focus on the observed behavior of economies with respect to foreign exchange reserves and interventions, given the evidence on interventions by floaters (in Calvo and Reinhart (2000a) and elsewhere), that perhaps only the US dollar truly floats freely for extended periods. ${ }^{9}$ While we do not deny the underlying empirical generalization, we believe such an approach to classifying exchange rate regimes assumes the result. It is of course possible that there is no real difference between floating and fixing central banks in behavior, but there still could be a very significant difference in their effects on expectations - the dirty floater who temporarily wanders 2.8 percent away from an undeclared central parity might be treated very differently by the markets from a central banker whose currency lurches outside a publicly announced $+/-2.5$ percent band. The same issue comes up in discussion of central bank autonomy and of monetary targets: it is possible that a central bank lacking legal protection from demands to make primary purchases of government debt monetizes no more debt than the legally independent central bank in its neighbor, but the credibility effects of that behavior lacking a legal guarantee might be different.

In short, it is our view that whether the implications of different declared regimes for central bank behavior and relevant macroeconomic outcomes indeed differ is an empirical question requiring

\footnotetext{
${ }^{9}$ Recently, Levy-Yeyati and Sturzenegger (2001a, b) have taken this ex post behavior approach.
} 
investigation. It remains possible that formal peggers and dirty floaters both behave and are treated the same, just as it is possible that legally independent and dependent central banks both resist monetization of debt and get the same credibility from so doing — that is the falsifiable null hypothesis that declared regimes do not matter. If so, then we should observe no statistically significant difference between regime types in our analyses. (It turns out that we $d o$, in fact, observe such differences.) Going to the opposite end of skepticism about monetary policy announcements (although often voiced by the same skeptics), it is possible that any given regime that allows any discretion will lead to a wide range of central bank behavior because it is not truly constraining. If this were so, then we would be able to discern little or no effect in such cases. (Again, this turns out not to be the case.) For our purposes, the point of the categorization is the extent and manner to which monetary discretion is constrained by an explicit exchange rate rule or domestic target. It is equally possible to argue a priori, for example, that even if floaters choose to manage their exchange rates heavily, they are not constrained to do so to the same degree as the publicly fixed. ${ }^{10}$

On the matter of announced domestic target, which is thought to be roughly correlated with transparency of communication to the domestic public, we divide our cases into five categories: "currency board," which denotes whenever domestic monetary sovereignty has been completely given up; "narrow money target," which covers base money or high powered money targeting through M1 targets; "broad money target" which includes all broader aggregates including domestic credit growth targets; "inflation target" which requires an explicitly announced numerical inflation goal; and "none" for those regimes without any sort of announced domestic targets. By these criteria, the US Federal Reserve remained a money targeter until 1993, despite its earlier de facto abandonment of monetary aggregates (see Friedman and Kuttner 1996), and is currently is in the category of "none" for announced domestic target in spite of some observers' characterization of the Fed as an "implicit inflation targeter" (e.g., Clarida, Galí and Gertler 1998 and Mishkin 2000). Again, since the point of this category is about classifying according to the public signal given for accountability and communication, not about whether the announced domestic target produces rule-like behavior by the central bank (which no monetary targeter has ever exhibited), this is consistent. This classification, in fact, allows us to test over the sample whether an implicit inflation targeter is different from an explicit one, rather than assuming the result.

\footnotetext{
${ }^{10}$ The experience of Austria provides an interesting example of this distinction. According to the IMF classification, Austria was officially on a float from 1974-94, despite increasingly narrowly pegging the deutsche mark over this period, and then publicly committing to the multilateral peg of the ERM. (See Glück and Hochreiter [2001]). Arguably, while Austria was behaviorally following a hard deutsche mark peg, known to the markets, over the entire period, the greater flexibility of its publicly declared commitments (first, a float, then, ERM wide-bands) may have contributed to the frameworks' success.
} 
Central bank autonomy is thought to be associated with counter-inflationary conservatism on the part of the central bank, both for theoretical (e.g., Rogoff 1985, Cukierman 1992) and empirical (e.g., Cukierman, Webb, and Neyapti 1992, Posen 1995) reasons. While many measures of central bank independence exist in the published literature, there are severe problems with these multi-faceted measures. ${ }^{11}$ Research has documented that the actual benefits of central bank independence stem from two observable narrow legal strictures: (1) whether the elected government is prevented from firing the central bank governor at will, and (2) whether there is a law preventing the central bank from being forced to purchase government debt directly from the government (monetize debt). Using country-by-country analyses, central bank documents, and occasional academic papers, we have coded all cases in our sample for central bank autonomy as either "none" if neither law exists, "partial" if one or the other but not both laws exist, and "full" if both laws are in place. Again, we use the term "autonomy" rather than "independence" so as to indicate the more narrowly defined measure we are using, not to stress any conceptual difference. Ideally, central bank autonomy will capture much of the monetary framework's reputation.

The dataset we have assembled contains 191 distinct monetary frameworks for 41 countries from the OECD, Latin America, and East Asia. (Future work will extend the analysis to countries in South Asia and Africa, and to the transition economies of eastern and central Europe.) Many of these frameworks are very short-lived, however, and therefore not amenable to our analysis. As described below in section three, we require for each framework a time series of sufficient length to calculate meaningful measures of exchange rate volatility and inflation persistence. For our baseline results, therefore, we limit the sample to frameworks lasting a minimum of 36 months after the breakdown of Bretton Woods in May 1973, which yields 124 usable cases.

This exclusion of short-lived frameworks naturally raises the question of survivorship bias, i.e., that those frameworks which are more unstable will be underrepresented in our sample. Indeed, the tabulation of framework duration by exchange rate regime displayed in figure 1 shows that while the number of floating rate and target zone regimes are similar across the 36-month duration split, there is a disproportionate number of hard peg regimes in the less-than-three-year category. Since many of these short-lived fixed rate regimes presumably ended catastrophically, this would tend to bias our results against finding high-variance (i.e., large devaluation) realizations, and perhaps make fixed-rate regimes appear more stable than they really are. Even with this potential bias, however, the sample contains ample

\footnotetext{
${ }^{11}$ See the discussion in Eijffinger and DeHaan (1996), Posen (1998, 1999), and Berger, Eijffinger, and DeHaan (2001), as well as the latter chapters of Cukierman (1992).
} 
evidence of instability among fixed-rate regimes. Furthermore, it turns out that varying the minimum duration cutoff (from 30 to 48 months) has little effect on the results on any of our estimates, not just those concerning exchange rate pegs. ${ }^{12}$

A more subtle distortion could be created by treating each frameworks equally, regardless of whether its duration was 36 months or 28 years. A reasonable question is whether the longer lasting frameworks share certain attributes. ${ }^{13}$ We partially address this possibility with the use of weighted least squares in our cross-sectional regressions below, where regime duration (in months) is used as the weight; again, it turns out to make little difference to our results.

Table 1 gives the distribution of framework elements for the 124 frameworks in our sample with a minimum duration of 36 months. (Note that a currency board represents both an exchange rate regime and an announced domestic target.) In terms of the correlations between exchange rate regime and announced domestic targets, hard pegs seem to make little use of domestic constraints, though a handful of instances exist. Otherwise, the spread among the remaining cells is rather even, with a wide variety of central bank autonomy levels within each cell.

\section{EMPIRICAL STRATEGY AND RESULTS}

This section investigates the effectiveness of monetary frameworks three distinct dimensions. One dimension is the variability of the nominal exchange rate itself. Because a stable exchange rate is more a means to an end, rather an end in itself, we also examine the level and persistence of inflation. These exchange rate and inflation results generally confirm of the findings of Frankel (1999) and Fischer (2001), but with some surprising twists. We also we use deviations from interest rate parity to characterize the stability of exchange rate expectations, and uncover possible "peso problems". Although the results of this analysis are less clear, they suggest that the exchange rate regime does indeed shape exchange rate expectations independent of domestic targets' and central bank autonomy's effects on inflation behavior.

Our empirical strategy combines time-series with cross-sectional analysis, but in a way that differs

\footnotetext{
${ }^{12}$ The results of these robustness checks, omitted for the sake of space, are available from the authors.

${ }^{13}$ The interpretation and welfare implications of such a relationship, if one exists, however, are unclear: it is not obvious that a stable framework is necessarily closer to optimal by virtue of being stable than well-considered changes between frameworks, so long as there is not excessive churning (which a three year minimum duration bar would seem to rule out). Moreover, it is not clear that those economies that switched regimes multiple times had different effects from subsequently-adopted frameworks than less-frequent switchers which adopted similar frameworks. (Chile and the United Kingdom both had multiple frameworks prior to the 1990s, for example, but their performance under inflation targeting has been similar to that of other countries.)
} 
from the classical panel data approach. The first step is to use the time-series dimension to compute exchange rate volatility, inflation performance, and forward premia statistics for each of the frameworks classified according to the criteria laid out above in section two. As discussed in that section, only frameworks with a duration sufficient to obtain reliable time series statistics are included in the sample; short-lived frameworks are dropped. In the second stage, those statistics are analyzed as a cross section, in which each country-framework combination is treated as a single observation.

Most of the data were taken from the International Monetary Fund's International Financial Statistics, as of end September 2000. The unit of observation for all the calculations is monthly, and exchange rates are from the last business day of each month. Wherever possible, three-month interest rates from the last business day of the month are used. ${ }^{14}$ Exchange rates and interest spread rates are generally expressed in terms of the US dollar and the three-month eurodollar rate. For European countries, however, the deutsche mark and the German three-month interbank rate are used as references.

\section{Exchange rate variability}

Seven measures are used to describe the variability (or stability) of exchange rates. The first two are the relatively obvious: the average rate of depreciation, and the standard deviation of monthly exchange rate changes. But as one goal of the analysis is to discern the effects of different monetary frameworks on both "normal" and "extreme" exchange rate movements, we consider three alternative volatility measures: the 25-75 percentile (i.e., interquartile, or 50 percent) and 5-95 percentile (i.e., 90 percent) ranges, as well as the standard deviation "trimmed" to remove one-month depreciations (increases) larger than 10 percent. To capture any asymmetry in the distribution of exchange rate changes, we also compute the coefficient of skewness; similarly, we calculate the coefficient of excess kurtosis to measure the degree to which the distribution is dominated by extreme observations. All of these are meant to capture the relative likelihood of a given exchange rate framework to 'break down,' that is suffer a large-scale devaluation. ${ }^{15}$

These time-series volatility measures are then regressed on a set of dummy variables representing the three elements of the monetary framework in an equation of the form:

\footnotetext{
14 In a few cases where more complete or better-documented data were available from the Federal Reserve Board or other central banks, these sources were used instead.

15 The suddenness of exchange rate regime breakdowns, even of pegs, should not be exaggerated. As a robustness check, we moved the end month of exchange rate pegs in our sample forward and backwards a month, to be sure our results were not driven by the precise timing and the inclusion of the specific days of sharp movements. This turns out to make no meaningful difference to the results.
} 


$$
\hat{v}_{i}^{\prime} \quad a \% \boldsymbol{b}_{x}^{\prime} \boldsymbol{x}_{i} \% \boldsymbol{b}_{m}^{\prime} \boldsymbol{m}_{i} \% \boldsymbol{b}_{a}^{\prime} \boldsymbol{a}_{i} \% \boldsymbol{b}_{c}^{\prime} \boldsymbol{c}_{i} \% e_{i}
$$

where $\hat{v}_{i}$ is the measure of exchange rate volatility in case $i, \boldsymbol{x}_{i}$ is a vector of exchange rate regime dummy variables (target zone/crawling peg, hard peg, and currency board), $\boldsymbol{m}_{i}$ is a vector of dummy variables for announced domestic targets (narrow money target, broad money target, and inflation target), $\boldsymbol{a}_{i}$ is a vector of dummy variables for central bank autonomy (partial and full), and $\boldsymbol{c}_{i}$ is a vector of control variables (dummies for the ERM zone, and whether the deutsche mark is used as the reference exchange rate). Table 2 reports results based on ordinary least-squares estimation of (1), and as a robustness check, weighted least-squares (WLS) estimates in which the error variance is assumed proportional to the inverse of the number of months in the framework.

The first column of panel A of table 2 displays the results of the OLS regression with the average depreciation rate as the dependent variable in (1). The estimated intercept indicates that countries with floating exchange rates, no announced domestic targets, and no central bank autonomy (i.e., $\boldsymbol{x}_{i}=\boldsymbol{m}_{i}=\boldsymbol{a}_{i}=$ $\boldsymbol{c}_{i}=0$ ) experience an average annual depreciation rate of 33 percent (positive numbers representing depreciation). As expected, hard peg regimes are associated with a significantly lower average rate of depreciation; depreciation is also lower for currency boards, but with only two observations in our sample, the coefficient is not statistically significant. Somewhat surprisingly, however, the standard deviation regression reported in the next column shows that other than a currency board (which effectively eliminates any exchange rate variability), none of the exchange rate regimes displays a statistically significantly lower volatility than a free float. Central bank autonomy, however, does appear to be associated with reduced volatility. The results are highly similar for the WLS regressions in panel B.

The story is rather different for those volatility measures that exclude extreme realizations. In the regressions involving the 50 percent and 90 percent ranges and the trimmed standard deviation, the harder exchange rate regimes do appear to limit "non-extreme" fluctuations, relative to a free float. Even the supposedly weaker target zone / crawling peg regimes show a reduction in these volatility measures, albeit of a smaller magnitude than that associated with a hard peg.

This diminished volatility in the non-extreme range comes at some costs, as would be expected. The significant positive constant in the skew regression indicates that while the distribution of exchange rate changes in the entire sample is skewed towards depreciation, this tendency is exaggerated for countries with hard exchange rate pegs. A similar result holds for excess kurtosis: the significant positive intercept in the kurtosis regression is a sign that the distribution of exchange rate changes has fat tails (leptokurtosis), meaning that there is has a high proportion of extreme movements, relative to the normal distribution, for 
these exchange rate regimes. The coefficient on the hard peg dummy shows that this tendency is dramatically exacerbated for fixed-rate regimes.

In other words, as discussed in the literature on exiting exchange rate commitments (e.g., Eichengreen, et al. 1998), the harder the peg the larger the depreciation upon exit. This result is particularly strong since, as discussed in the previous section, the survivorship bias of having fewer short-lived exchange rate pegs in the sample for estimation reasons should work against our finding this result. The consensus view that hard bilateral or fixed basket pegs are dangerous is borne out very strongly. Interestingly, central bank autonomy, whether partial or full, offsets much of the skew and the excess kurtosis (although the effect on kurtosis is not statistically significant). As hypothesized at the end of section one, it would appear that central bank autonomy has an independent effect on exchange rate volatility by enhancing the credibility of central bank conservatism vis-à-vis inflation, the exchange rate regime notwithstanding.

\section{Inflation}

A second aspect in the assessment of various monetary frameworks is their relative abilities to stabilize inflation. One obvious gauge of inflation performance is the average level of inflation, as in Ghosh et al. (1997) and Levy-Yeyati and Sturzenegger (2001b). Average inflation is certainly informative, but it may reveal more about size and structure of the economy, and the central banks' target inflation rates - which surely differ across time and place - than about the efficacy of policy per se. Similarly, inflation volatility (which we do not analyze) may be affected by a variety of factors that differ across countries, such as the degree of openness.

An arguably more informative gauge of a monetary framework's effectiveness is its ability to reduce inflation persistence. Low persistence means policy acts to return inflation to its (perhaps implicit) target after an inflation shock occurs. In the real world, this indicates that there is limited inflation passthrough or "second round effects," avoiding the wage-price spirals that are the bane of central banking. Conversely, a high degree of persistence means perturbations have relatively long-lived effects, reverting gradually to its mean. This would be consistent with an economy where the central bank is perceived as accommodative of inflation shocks and/or most price changes including those to relative prices are perceived as changes in the general price level. A unit root would indicate that inflation perturbations persist indefinitely in a given monetary framework; a root larger than unity would indicate an explosive process.

Following Watson (1999), we use the largest root of an estimated univariate AR(6) model as a 
measure of inflation persistence. ${ }^{16}$ As the rate of decay at long horizons is effectively governed by the largest root in the process, this provides a natural measure of inflation fluctuations' longevity. One statistical complication is the well-known small-sample downward bias inherent in least-squares estimates of the largest autoregressive root when that root is near unity. To correct for this bias, we also follow Watson (1999) in using the Stock (1991) method of calculating the median unbiased estimate of the root from the relevant Dickey-Fuller $t$-statistic. A regression similar to (1) is then used to assess the effects of policy, with average inflation $\mathrm{B}_{i}$ and the largest autoregressive root $\mathrm{C}_{i}$ replacing $\hat{v}_{i}$ as the dependent variable. The minimum duration was again set to 36 months, but incomplete price price data for a couple of countries cuts the sample down to 121 . OLS and WLS results appear in table 3.

All of the exchange rate and domestic regime dummies' coefficients in the average inflation regression (the first and third columns of table 3 ) have the expected sign, and many are significant at the 0.10 level or better. A hard exchange rate peg and greater central bank autonomy are both strongly associated with lower inflation. Money and inflation targets also appear to yield lower inflation, although the estimates are not significant when shorter-lived frameworks are downweighted in the WLS regression. In general, the more rule-like the regime (i.e., currency boards and narrow money targets), the larger is the inflation reduction. Once monetary frameworks as a whole, including domestic and autonomy aspects, are accounted for, however, there is no significant effect on average inflation from ERM membership or the alignment with the deutsche mark. This result suggests that there is nothing unique in that particular arrangement relative to other target zone regimes - it also implies that our results are not driven by the

inclusion of wealthy stable economies in our sample, but that the frameworks matter for emerging and wealthy economies alike.

The inflation persistence results tell a very different story, however. Only inflation targeting is associated with a large, significant reduction in inflation persistence; ceteris paribus, the adoption of an inflation target would bring the root of the inflation time-series down from 0.84 to 0.74 . Exchange rate constraints and central bank autonomy are of little or no help in reducing the persistence of inflation none of these elements is associated with a significant reduction in the largest AR root. (Indeed, ERM members' inflation rates appear to display somewhat greater persistence.) Remember that this result in our sample is only for explicit inflation targeters who declare their regime, not for those central banks that merely make inflation their internal priority, and thus it cannot simply be ascribed to the broader shift

\footnotetext{
${ }^{16}$ Because only quarterly price data are available for New Zealand, in that case an AR(2) is estimated, and the autoregressive root corresponding to a monthly frequency calculated as $D_{i}^{1 / 3}$.
} 
towards counter-inflationary monetary policies among most central banks in the 1990s. ${ }^{17}$

This result extends the findings of Kuttner and Posen (1999) for the United Kingdom, New

Zealand, and Canada, further supporting that paper's view that moving closer to the "optimal state contingent rule" reduces inflation persistence without increasing the level of inflation, exchange rate, or real output volatility. This is because a transparent commitment to a long-run inflation target allows the central bank to respond more flexibly to shocks in the short run. If much of the costs of disinflation are associated with inflation persistence, as most monetary theory suggest (see the discussion in Walsh 1998, chapter 8), this would suggest that inflation targeting could improve economic welfare.

\section{Forward premia}

Our third, and perhaps most subtle gauge of monetary framework's effects has to do with the pervasiveness of deviations from forward premia - predictable excess returns relative to the uncovered interest rate parity (UIP) benchmark. Persistent, positive excess returns on domestic currency-denominated assets may signal a lack of credibility of commitment to low inflation and/or a strong currency, as in the classic "peso problem." A positive correlation between excess returns and the interest rate spread would also be associated with a lack of credibility: one in which interest rate hikes were needed to defend the exchange rate from attack, and were used.

To uncover these sorts of exchange regime vulnerabilities, we first calculate the excess return $R_{t+k}$ on $k$-period domestic bonds (purchased at time $t$ ), relative to foreign bonds,

$$
\mathrm{R}_{t \%} \cdot \frac{\left(1 \% r_{t}\right)\left(1 \% s_{t}\right)}{\left(1 \% s_{t \%}\right)\left(1 \% r_{t}^{(}\right)} \& 1
$$

where $r$ and $r^{*}$ represent the (risk-free) $k$-period domestic and foreign nominal interest rates, and $s$ is the exchange rate, measured in domestic currency per unit of foreign currency. If uncovered interest rate parity holds, then the spread between foreign and domestic interest rates should reflect the expected depreciation of the domestic currency, and there should be no predictable excess return. In this case, the average forward

\footnotetext{
${ }^{17}$ It is possible that these inflation persistence results are even stronger than characterized here, because there are theoretical and empirical arguments that inflation persistence rises as the level of inflation declines - therefore, in the 1990s, as inflation targeting economies disinflated to lower inflation levels, their level of inflation persistence should have increased, ceteris paribus.
} 
premium and the estimated $\hat{\mathcal{L}}$ from the regression,

$$
\mathrm{R}_{t / \mathrm{t}}, \quad \% 2\left(r_{t} \& r_{t}^{(}\right) \%,{ }_{t} \%
$$

should both equal zero. ${ }^{18}$

The empirical failure of this equation is well known: estimates of equations like (3) almost invariably find positive, highly signifcant $\hat{2}$ s. This has spawned a vast literature attempting to rationalize the anomaly (see Engel 1996 for a survey). Examining further evidence of this as an anomaly for UIP, however, is not our goal. Instead, we wish to see whether the empirical failure of the relationship as an indicator of credibility problems is in related in any way to aspects of exchange rate regimes. From this standpoint, the most relevant explanation is that proposed by Evans and Lewis (1995), who showed that at least part of the anomaly can be traced a "peso problem" in which the market puts some expectations on the possibility of a future depreciation that is not observed in the sample.

Our approach, then, is to relate the $\hat{2}$ s estimated from (3) to the vector of exchange rate regime dummies $\boldsymbol{x}_{i}$, a dummy for ERM membership (the scalar $c_{i}$ ), and the standard deviation of the exchange rate $\left(\mathrm{F}_{i}\right)$ via the regression

$$
\hat{2}_{i}{ }^{\prime} a \% \boldsymbol{b}_{x}^{\prime} \boldsymbol{x}_{i} \% b_{c} c_{i} \% b_{\mathrm{F}} \mathrm{F}_{i} \% e_{i}
$$

and an analogous equation for the average $k$-month forward premium, $\mathrm{R}_{k, i}$. The domestic policy constraint and central bank autonomy dummies are uniformly small and insignificant, and are therefore dropped from this analysis. ${ }^{19}$ Since forward premia are highly volatile, a slightly longer minimum duration of 48 months was chosen; this, along with the lack of reliable interest rate data for many countries, reduces the sample to 87 observations.

Results from this regression appear in table 4. Instead of the raw regression coefficients, the table reports the fitted $\hat{2}$ and $\mathrm{R}_{k}$ for each framework, calculated from the relevant linear combination of regression coefficients. For example: the $\hat{2}$ for exchange rate pegs would be computed as the intercept $a$ plus the coefficient on the exchange rate peg dummy, plus $b_{\mathrm{F}}$ times the average standard deviation for the

\footnotetext{
${ }^{18}$ This regression, with log-linearized $\mathrm{R}$, is equivalent to the conventional Fama (1984) regression of the $k$-period change in the exchange rate on the spread between the forward and spot exchange rates, which in turn is equal to the spread between $k$-period interest rates under covered interest rate parity.

${ }^{19}$ This would appear to be consistent with the results in tables 2 and 3 that the various aspects of monetary frameworks do work through different channels to have their effect.
} 
fixed-rate regimes.

The first and third columns of the table show the average forward premium for the various exchange rate regimes, distinguishing between the ERM and other target zone / crawling peg regimes. These average premia vary widely, and are not generally statistically significant. The one exception is the case of the non-ERM target zone / crawling peg, which is associated with a significant (albeit marginally in the case of WLS), positive premium. This may result either from a "peso problem," or the more frequent occurrence of that exchange rate regime among countries more prone to devaluation risk.

The second and fourth columns report the fitted $\hat{2}_{\mathrm{s}}$ for the different regimes. The $\hat{\mathbf{z}}_{\mathrm{s}}$ are uniformly positive, and (except for the non-ERM target zone / crawling peg case) statistically significant, further confirming the ubiquity of the forward premium puzzle. For the ERM, hard peg and currency board cases, the coefficients are very near unity, reflecting the fact that with the exchange rate fixed, a positive home - foreign interest rate spread translates one-for-one into excess returns (abstracting from default risk). The coefficient is close to 2 for floating rate regimes, indicating that, contrary to theory, positive interest rate spreads are associated with an appreciating exchange rate for these regimes. Only in the non-ERM target zones / crawling peg case is the average $\hat{2}$ no longer significant.

\section{CONCLUSIONS}

The impacts of exchange rate regimes, central bank autonomy, and, to a lesser degree, announced domestic targets, on monetary policy goals have usually been considered in isolation from one another. The recent discussion of polar extremes for exchange rate regimes has exemplified this tendency. If ever considered in conjunction, these three aspects of an economy's monetary framework typically have been viewed interchangeably as rule-like constraints binding the hands of policymakers to varying degrees. Current empirical research, which focuses on the revealed behavior of central banks, rather than on their declared regimes and the outcomes of those, has tended to further narrow the discussion to a unidimensional spectrum of fixity-versus-flexibility.

The results in this paper have demonstrated that this unidimensional view is incomplete, and in some ways misleading. These results draw on a newly created dataset bringing together data on exchange rate regime, announced domestic targets, and central bank autonomy for 41 developed and emerging market economies - nearly 200 distinct frameworks spanning three decades. This dataset's richness enabled us to jointly analyze and compare the effects all three elements of the monetary framework, and highlight the relative strengths and weakness of each.

The results show that exchange rate commitments do act like the rules they are presumed to be, 
resulting in fewer small exchange rate movements, and lower inflation; they also appear to affect the behavior of the forward premium. A stronger commitment, in the form of a hard peg, confers larger counterinflationary benefits, but at the cost of a greater likelihood of large devaluations (manifested in the data as greater skewness and kurtosis). Hard pegs are indeed brittle.

The exchange rate regime is only one dimension of the monetary framework, however. The results also show that central bank autonomy is also associated with a reduction in exchange rate volatility, and in the level of inflation, consistent with its interpretation as a signal of more "conservative" central bank preferences. Inflation targeting also significantly reduces average inflation, but only inflation targeting is associated with a reduction with inflation persistence. This is consistent with its interpretation as a transparency-enhancing device, which moves the central bank closer to the optimal state-contingent rule. A multidimensional monetary framework that includes these additional two elements therefore offers many of the benefits of a hard exchange rate peg, but without its brittleness.

This paper therefore advances the current state of research in several ways. The first is the creation of a large, well-documented dataset containing information on all three aspects of monetary frameworks. Second, by rejecting the hypotheses that declared monetary policy commitments either matter less to outcomes than central bank behavior, or are too loose a rule to determine behavior in a consistent fashion, we show that differences in declared regimes do matter. Third, we demonstrate that central bank autonomy and announced domestic targets have significant effects on relevant monetary policy outcomes even controlling for exchange rate commitments. Fourth, by examining novel measures of exchange rate volatility, and by considering inflation persistence rather than just its level, we demonstrate that these various aspects of monetary frameworks not only have independent effects, but also differing effects. Fifth, the breadth of the dataset allows the most comprehensive comparison to date of outcomes under explicitly announced inflation targeting with those under other monetary frameworks.

There are obviously several limitations to this work, which should spur further research. First, our dataset is a work in progress, and does not yet incorporate data on the monetary frameworks of many emerging market economies. Further work is required to verify that the results in the paper hold for a more diverse set of economies. Second, the reasons for adopting a particular monetary framework remain unexplored; this leaves open the possibility that a common unobserved factor determines the adoption and success of monetary frameworks. Third, the analysis was limited to nominal variables like exchange rates and inflation. This reflected a conscious decision to focus on those variables that are directly linked to monetary policy decisions, but there is also room for considering the effect on real outcomes. (Such research would require taking a broader set of control variables into account, of course.) Fourth, our conclusion that 
a flexible combination monetary framework could dominate a brittle unidimensional commitment depends upon assumptions about the welfare costs of large devaluations and of reduced inflation persistence relative to those of other variables. A more explicit welfare criterion would allow for a more definitive evaluation of policy alternatives than we were able to undertake in this paper. 


\section{REFERENCES}

Akerlof, George, William Dickens and George Perry (2000), "Near-Rational Wage and Price Setting and the Long-Run Phillips Curve," Brookings Papers on Economic Activity 1: 1-44.

Ball, Laurence (1999), “Efficient Rules for Monetary Policy,” International Finance 2(1): 63-84.

Berger, Helge, Jakob de Haan, and Sylvester Eijffinger (2001), "Central Bank Independence: An Update of Theory and Evidence," Journal of Economic Surveys, 15(1): 3-40.

Bernanke, Ben S., Thomas Laubach, Frederic S. Mishkin, and Adam S. Posen (1999), Inflation Targeting: Lessons from the International Experience, Princeton: Princeton University Press.

Calvo, Guillermo A. and Carmen M. Reinhart (2000a), “Fear of Floating,” NBER Working Paper no. 7993.

Calvo, Guillermo A. and Carmen M. Reinhart (2000b), "Fixing For Your Life," NBER Working Paper no. 8006.

Campillo, Marion and Jeffrey Miron (1997), “Why Does Inflation Differ Across Countries?" in Reducing Inflation: Motivation and Strategy, Christina Romer and David Romer, eds. Chicago: University of Chicago Press.

Clarida, Richard, Jordi Galí and Mark Gertler (1998), "Monetary Policy Rules in Practice: Some International Evidence,” European Economic Review 42(6), June: 1033-67.

Cukierman, Alex (1992), Central Bank Strategy, Credibility, and Independence, Cambridge, MA: MIT Press.

Cukierman, Alex, Steven Webb, and Bilin Neyapti (1992), "Measuring the Independence of Central Banks and its Effects on Policy Outcomes," The World Bank Economic Review 6, 353-98.

Drazen, Allen and Paul Masson (1994), "Credibility of Policies versus Credibility of Policymakers," Quarterly Journal of Economics, 109(3): 735-54.

Eichengreen, Barry and Ricardo Hausmann (1999), “Exchange Rates and Financial Fragility,” NBER Working Paper no. 7418.

Eichengreen, Barry, Paul Masson, Hugh Bredenkamp, Barry Johnston, Javier Haman, Esteban Jadresic, and Inci Oetker (1998), "Exit Strategies: Policy Options for Countries Seeking Greater Exchange Rate Flexibility," IMF Occasional Paper no. 168.

Eijffinger, Sylvester and Jakob de Haan (1996), "The Political Economy of Central Bank Independence," Princeton Special Papers in International Economics no. 19.

Engel, Charles, "The Forward Discount Anomaly and the Risk Premium: A Survey of Recent Evidence," Journal of Empirical Finance 3: 123-92.

Evans, Martin D. D. and Karen K. Lewis (1995), "Do Long-Term Swings in the Dollar Affect Estimates of 
the Risk Premia?" Review of Financial Studies 8 (Autumn): 709-42.

Fama, Eugene F. (1984), "Forward and Spot Exchange Rates," Journal of Monetary Economics 14: 319-38.

Fischer, Stanley (2001), "Exchange Rate Regimes: Is the Bipolar View Correct?" Journal of Economic Perspectives 15 (Spring): 3-24.

Frankel, Jeffrey A. (1999), "No Single Currency Regime is Right for All Countries or At All Times," Princeton University, International Finance Section, Essays in International Finance no. 215, August.

Friedman, Benjamin and Kenneth Kuttner (1996), "A Price Target for U.S. Monetary Policy? Lessons from the Experience with Money Growth Targets," Brookings Papers on Economic Activity 1: $77-146$.

Ghosh, Atish R., Anne-Marie Gulde, Jonathan D. Ostry, and Holger C. Wolf (1997), "Does the Nominal Exchange Rate Regime Matter?” NBER Working Paper no. 5874.

Glück, Heinz and Eduard Hochreiter (2001), "Exchange Rate Policy in the Transition to Accession: Any Lessons from the Austrian Experience?" Photocopy..

King, Mervyn (1997), "Rules and Discretion in the UK Monetary Framework," Journal of Monetary Economics.

Kuttner, Kenneth and Adam Posen (1999), "Does Talk Matter After All? Inflation Targeting and Central Bank Behavior.” Institute for International Economics Working Paper no. 99-10.

Kuttner, Kenneth and Adam Posen (2000), "Inflation, Monetary Transparency, and G-3 Exchange Rate Volatility," in Adapting to Financial Globalization, Routledge, Eduard Hochreiter, ed., forthcoming.

Laubach, Thomas and Adam Posen (1997), "Disciplined Discretion: Monetary Targeting in Germany and Switzerland," Princeton Essays in International Finance, December.

Levy-Yeyati, Eduardo and Federico Sturzenegger (2001a), "To Float or to Trail: Evidence on the Impact of Exchange Rate Regimes,” Working paper, Universidad Torcuato Di Tella.

Levy-Yeyati, Eduardo and Federico Sturzenegger (2001b), "Exchange Rate Regimes and Economic Performance," Working paper, Universidad Torcuato Di Tella.

Mishkin, Frederic (2000), “What should central banks do?” Federal Reserve Bank of St. Louis Review, November/December, 1-14.

Mussa, Michael, Paul Masson, Alexander Swoboda, Esteban Jadresic, Paolo Mauro, and Andrew Berg (2000), "Exchange Rate Regimes in an Increasingly Integrated World Economy,” IMF Occasional 
Paper no. 193.

Posen, Adam (1995), "Declarations are not Enough: Financial Sector Sources of Central Bank Independence," in NBER Macroeconomics Annual 1995, B. Bernanke and J. Rotemberg, eds. Cambridge, MA: MIT Press.

Posen, Adam (1998), “Central Bank Independence and Disinflationary Credibility: A Missing Link?”, Oxford Economic Papers, 50, July: 335-59.

Posen, Adam (1999), "No Monetary Masquerades for the ECB," in Ellen Meade, ed., The European Central Bank: How Accountable? How Decentralized? American Institute for Contemporary German Studies.

Rogoff, Kenneth (1985), “The Optimal Degree of Commitment to an Intermediate Target," Quarterly Journal of Economics 100(4): 1169-89.

Siklos, Pierre (2000), "Is the MCI a Useful Signal of Monetary Policy Conditions? An Empirical Investigation," International Finance, 3(3): 413-38.

Stock, James H. (1991), "Confidence Intervals for the Largest Autoregressive Root in U.S. Macroeconomic Time Series," Journal of Monetary Economics 28, December: 435-59.

Summers, Lawrence H. (2000), "International Financial Crises: Causes, Prevention, and Cures," American Economic Review, Papers and Proceedings, 90 (2): 1-16.

Svensson, Lars (1999), “Price Level Targeting vs. Inflation Targeting: A Free Lunch?” Journal of Money, Credit and Banking 31: 277-95.

Walsh, Carl E. (1998), Monetary Theory and Policy, Cambridge: MIT Press.

Watson, Mark W. (1999), "Explaining the Increased Variability in Long-Term Interest Rates," Federal Reserve Bank of Richmond Economic Quarterly 85, Fall: 71-96.

Williamson, John (2000), Exchange Rate Regimes for Emerging Markets: Reviving the Intermediate Option, Washington: Institute for International Economics. 
Figure 1 Duration of monetary frameworks, tabulated by exchange rate regime

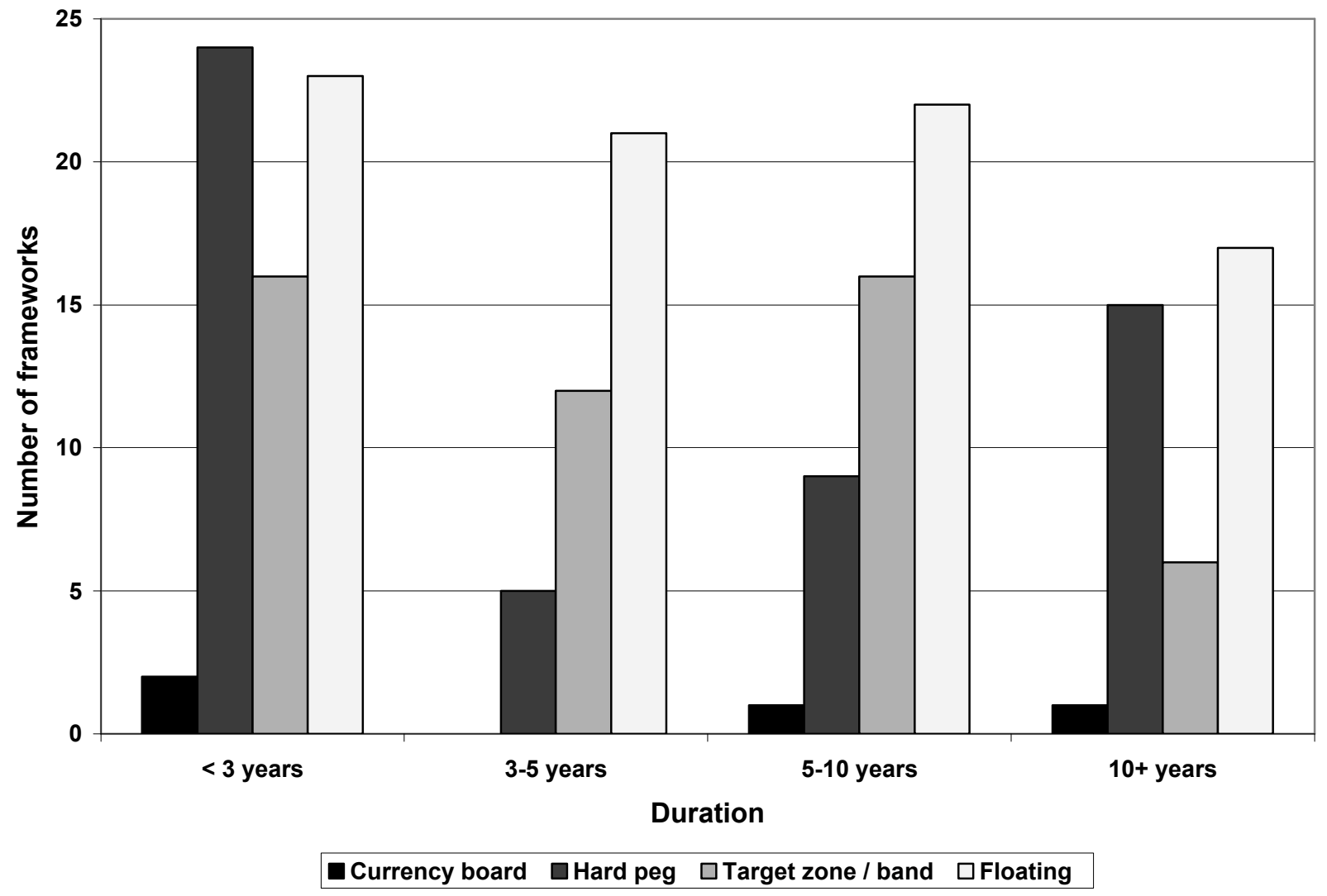


Table 1 Summary of exchange rate regimes, domestic policy and Central Bank autonomy

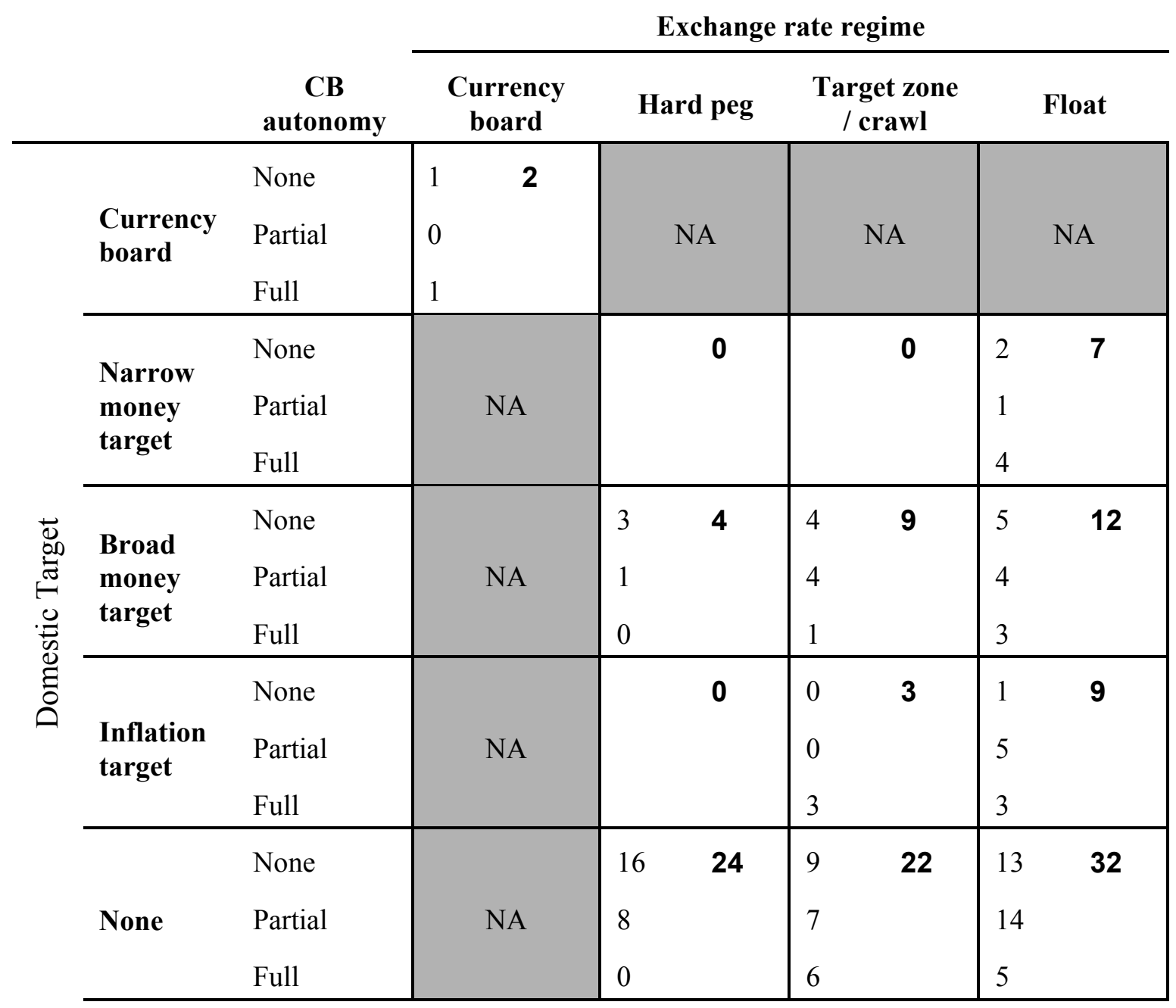

$\mathrm{NA}=$ not applicable

Notes: numbers represent the number of observations in our sample for each combination of exchange rate regime, announced domestic target, and central bank autonomy. The bold numbers in the upper right-hand corner of each cell is the total for that particular combination of exchange rate regime and announced domestic target. 
Table 2 Estimated effect of monetary framework on exchange rate volatility

A. Method $=$ Ordinary Least Squares

\begin{tabular}{|c|c|c|c|c|c|c|c|}
\hline \multirow[b]{2}{*}{ Regressor } & \multicolumn{7}{|c|}{ Dependent variable } \\
\hline & $\begin{array}{c}\text { Average } \\
\text { depreciation }\end{array}$ & $\begin{array}{l}\text { Standard } \\
\text { deviation }\end{array}$ & $\begin{array}{l}50 \text { percent } \\
\text { range }\end{array}$ & $\begin{array}{l}90 \text { percent } \\
\text { range }\end{array}$ & $\begin{array}{l}\text { Trimmed } \\
\text { SD }\end{array}$ & Skew & $\begin{array}{c}\text { Excess } \\
\text { kurtosis }\end{array}$ \\
\hline Constant & $33.3^{* * *}$ & $6.0^{* * *}$ & $2.6^{* * *}$ & $9.8^{* * *}$ & $2.0^{* * *}$ & $3.2 * * *$ & $27.8^{* *}$ \\
\hline Currency board & -25.3 & $-5.2^{* *}$ & $-2.7 * *$ & $-9.8 * *$ & $-1.9^{* * *}$ & 2.2 & 16.4 \\
\hline Hard peg & $-16.3 * * *$ & -0.1 & $-1.7 * * *$ & $-5.3 * * *$ & $-1.0 * * *$ & $3.2 * * *$ & $43.4^{* * *}$ \\
\hline Target zone & -7.9 & -1.1 & $-0.9 * *$ & -2.5 & $-0.6 * * *$ & 0.6 & 4.2 \\
\hline Narrow money target & $-18.0^{*}$ & -1.1 & $\dagger$ & -0.6 & 0.4 & -1.2 & -8.7 \\
\hline Broad money target & -9.2 & -1.0 & 0.1 & -0.3 & 0.2 & -0.6 & -6.1 \\
\hline Inflation target & $-14.4^{*}$ & -1.2 & $\dagger$ & -1.9 & 0.1 & -0.7 & -7.2 \\
\hline Partial CB autonomy & $-8.7^{*}$ & $-2.1 * * *$ & $\dagger$ & -0.8 & $\dagger$ & $-1.4^{* *}$ & -13.1 \\
\hline Full CB autonomy & $-15.9^{* *}$ & $-1.6^{*}$ & 0.3 & 0.1 & $\dagger$ & $-1.9^{* * *}$ & -12.1 \\
\hline DM benchmark & -7.0 & $-1.9^{* * *}$ & $\dagger$ & -1.5 & 0.1 & $-1.6^{* * *}$ & $-20.1 * * *$ \\
\hline ERM zone & -0.2 & -0.1 & $-1.0^{*}$ & -2.1 & $-0.7^{* *}$ & 0.7 & 9.3 \\
\hline R-squared & 0.177 & 0.222 & 0.239 & 0.144 & 0.312 & 0.369 & 0.279 \\
\hline
\end{tabular}


Table 2 (continued)

B. Method $=$ Weighted Least Squares

\begin{tabular}{|c|c|c|c|c|c|c|c|}
\hline \multirow[b]{2}{*}{ Regressor } & \multicolumn{7}{|c|}{ Dependent variable } \\
\hline & $\begin{array}{c}\text { Average } \\
\text { depreciation }\end{array}$ & $\begin{array}{l}\text { Standard } \\
\text { deviation }\end{array}$ & $\begin{array}{l}50 \text { percent } \\
\text { range }\end{array}$ & $\begin{array}{l}90 \text { percent } \\
\text { range }\end{array}$ & $\begin{array}{l}\text { Trimmed } \\
\text { SD }\end{array}$ & Skew & $\begin{array}{c}\text { Excess } \\
\text { kurtosis }\end{array}$ \\
\hline Constant & $23.7 * * *$ & $5.5^{* * *}$ & $2.0 * * *$ & $7.1 * * *$ & $1.7 * * *$ & $3.6 * * *$ & $39.3 * * *$ \\
\hline Currency board & $-21.6^{* *}$ & $-5.2 * * *$ & $-2.0^{* * *}$ & $-7.0 * * *$ & $-1.7 * * *$ & -1.5 & -24.7 \\
\hline Hard peg & $-11.5^{* *}$ & 0.4 & $-1.5^{* * *}$ & $-4.7 * * *$ & $-1.0 * * *$ & $4.9 * * *$ & $72.2 * * *$ \\
\hline Target zone & -3.5 & -1.0 & $-0.6^{*}$ & -1.8 & $-0.5^{* *}$ & 0.8 & 5.4 \\
\hline Narrow money target & -11.6 & -0.8 & 0.3 & 0.4 & 0.4 & -1.0 & -13.8 \\
\hline Broad money target & -4.9 & -1.0 & 0.3 & 0.6 & 0.3 & -0.4 & -9.4 \\
\hline Inflation target & -9.1 & -0.9 & 0.4 & -0.4 & 0.2 & -1.0 & -16.6 \\
\hline Partial CB autonomy & -5.8 & $-2.1 * * *$ & 0.3 & 0.6 & 0.3 & $-1.8^{* *}$ & -20.3 \\
\hline Full CB autonomy & $-12.6^{*}$ & $-1.9 *$ & 0.1 & -0.3 & -0.1 & $-1.9 *$ & -10.0 \\
\hline DM benchmark & -2.6 & $-1.4^{*}$ & 0.2 & $\dagger$ & 0.2 & $-2.1 * * *$ & $-32.7 * * *$ \\
\hline ERM zone & -5.2 & -0.2 & $-1.1 * *$ & -2.6 & $-0.7 * *$ & 0.8 & 10.8 \\
\hline R-squared & 0.102 & 0.301 & 0.215 & 0.068 & 0.322 & 0.607 & 0.481 \\
\hline
\end{tabular}

Notes: Number of observations $=124$. Statistical significance is denoted by asterisks: $* * *$ for coefficients significant at the 0.01 level, $* *$ and $*$ for coefficients significant at the 0.05 and 0.10 levels respectively. The $\uparrow$ symbol denotes coefficients less than 0.05 in absolute value. The sample excludes regimes lasting less than 36 months, and one hyperinflationary episode. European exchange rates (except Germany's) are expressed in terms of the DM; Germany's is relative to the U.S. dollar. A narrow trade-weighted exchange rate is used for the U.S. In weighted-least-squares regressions (panel B), the error variance assumed proportional to the inverse of the number of months in each regime. 
Table 3 The estimated effect of monetary framework on inflation and its persistence

\begin{tabular}{|c|c|c|c|c|}
\hline \multirow[b]{3}{*}{ Regressor } & \multicolumn{2}{|c|}{ Method: OLS } & \multicolumn{2}{|c|}{ Method: WLS } \\
\hline & \multicolumn{2}{|c|}{ Dependent variable } & \multicolumn{2}{|c|}{ Dependent variable } \\
\hline & Inflation level & Persistence & Inflation level & Persistence \\
\hline Constant & $30.1 * * *$ & $0.84 * * *$ & $23.3 * * *$ & $0.84 * * *$ \\
\hline Currency board & -20.8 & $\S$ & $-18.8^{* *}$ & $\S$ \\
\hline Hard peg & $-11.4 * *$ & 0.04 & $-7.6^{* *}$ & 0.03 \\
\hline Target zone & -2.1 & 0.03 & 0.1 & $\S$ \\
\hline Narrow money target & $-14.0^{*}$ & -0.03 & -8.1 & -0.02 \\
\hline Broad money target & $-7.6^{*}$ & -0.03 & -4.2 & -0.02 \\
\hline Inflation target & $-11.4^{*}$ & $-0.11^{* *}$ & -8.1 & $-0.11^{* *}$ \\
\hline Partial CB autonomy & $-7.5^{*}$ & -0.03 & $-6.2 *$ & -0.03 \\
\hline Full CB autonomy & $-14.4^{* * *}$ & -0.04 & $-11.9^{* *}$ & -0.04 \\
\hline DM benchmark & -5.6 & $-0.06^{* *}$ & -1.9 & -0.03 \\
\hline ERM zone & -3.7 & $0.10^{*}$ & -7.2 & $0.10^{* *}$ \\
\hline R-squared & 0.230 & 0.163 & 0.160 & 0.871 \\
\hline
\end{tabular}

Notes: Number of observations $=121$. Statistical significance is denoted by asterisks: $* * *$ for coefficients significant at the 0.01 level, $* *$ and $*$ for coefficients significant at the 0.05 and 0.10 levels respectively. The $\S$ symbol denotes coefficients less than 0.005 in absolute value. Inflation persistence is measured by the median-unbiased estimate of the largest autoregressive root from a univariate AR(6) fitted to the inflation rate. Inflation rates are computed from the CPI, or if that is not available, from the PPI. The sample excludes regimes lasting less than 36 months, and one hyperinflationary episode. WLS regressions assume the error variance is proportional to the inverse of the number of months in each regime. 
Table 4 The effect of monetary framework on the forward premium

\begin{tabular}{|c|c|c|c|c|}
\hline \multirow[b]{2}{*}{ Exchange rate regime } & \multicolumn{2}{|c|}{ Method: OLS } & \multicolumn{2}{|c|}{ Method: WLS } \\
\hline & Average premium & Slope coefficient & Average premium & Slope coefficient \\
\hline \multirow[t]{2}{*}{ Floating exchange rate } & 0.8 & 2.13 & 0.3 & 1.94 \\
\hline & (7.9) & $(0.3)$ & $(5.6)$ & $(0.3)$ \\
\hline \multirow[t]{2}{*}{ Non-ERM target zone or crawl } & 23.0 & 0.71 & 15.0 & 0.60 \\
\hline & $(10.8)$ & $(0.5)$ & $(8.9)$ & $(0.5)$ \\
\hline \multirow[t]{2}{*}{ ERM zone } & 5.1 & 1.46 & 5.3 & 1.00 \\
\hline & $(13.8)$ & $(0.6)$ & $(10.2)$ & $(0.5)$ \\
\hline \multirow[t]{2}{*}{ Hard peg } & 2.9 & 1.57 & -1.1 & 1.00 \\
\hline & $(12.1)$ & $(0.5)$ & (7.5) & $(0.4)$ \\
\hline \multirow[t]{2}{*}{ Currency board } & 5.3 & 1.00 & 5.2 & 1.00 \\
\hline & $(49.1)$ & $(2.0)$ & $(17.4)$ & $(0.9)$ \\
\hline
\end{tabular}

Notes: Number of observations $=87$. Standard errors appear in parentheses. The forward premium is measured as the ex post annualized foreign (i.e., dollar or DM) excess return from investing in domestic short-term debt. The slope coefficient is from the regression of the forward premium on the (domestic - foreign) interest rate spread. The sample excludes regimes lasting less than 48 months, and those countries for which reliable interest rate data were not available. WLS regressions assume the error variance is proportional to the inverse of the number of months in each regime. 